Int. J. Electrochem. Sci., 16 (2021) Article ID: 210244

International Journal of

ELECTROCHEMICAL

SCIENCE

www.electrochemsci.org

\title{
Impact of Hydrogen Peroxide and Albumin on the Corrosion Behavior of Titanium Alloy (Ti6Al4V) in Saline Solution
}

\author{
Benea Lidia*, Simionescu Nicoleta \\ Competence Center: Interfaces-Tribocorrosion-Electrochemical Systems, Dunarea de Jos University of \\ Galati, 47 Domnească Street, RO-800008, Galati, Romania \\ *E-mail: Lidia.Benea@ugal.ro
}

doi: $10.20964 / 2021.02 .39$

Received: 5 October 2020 / Accepted: 23 November 2020 / Published: 31 December 2020

\begin{abstract}
In this study our goal was to monitoring the corrosion behavior of titanium alloy (TI6Al4V) in four solution: saline solution, saline solution with addition of $1 \% \mathrm{H}_{2} \mathrm{O}_{2}$, saline solution with $1 \%$ albumin and saline solution with mixed $1 \%$ albumin $+1 \% \mathrm{H}_{2} \mathrm{O}_{2}$ in order to see the synergistic effects of this two compound in combination. It is known that $\mathrm{H}_{2} \mathrm{O}_{2}$ is a ROS (reactive oxygen species) which appear in human body when inflammatory reactions occur and albumin it is used because is a protein (the most abundant) from the human body. In vitro studies for corrosion behavior of titanium alloy (TI6Al4V) in a presence of saline solution, $\mathrm{H}_{2} \mathrm{O}_{2}$ and albumin in this study were investigated by different electrochemical measurements: OCP (open circuit potential), PD (potentiodynamic polarization curves) and EIS (electrochemical impedance spectroscopy). From the electrochemical results we can say that the presence of $\mathrm{H}_{2} \mathrm{O}_{2}$ in the saline solution decreases the corrosion resistance of the TI6Al4V alloy, while the presence of albumin in the saline solution acts as an inhibitor and the corrosion resistance of TI6Al4V alloy increases as compared to the solution in which it was added $\mathrm{H}_{2} \mathrm{O}_{2}$.
\end{abstract}

Keywords: Corrosion resistance; Titanium alloy; Reactive oxygen species; Albumin.

\section{$\underline{\text { FULL TEXT }}$}

(C) 2021 The Authors. Published by ESG (www.electrochemsci.org). This article is an open access article distributed under the terms and conditions of the Creative Commons Attribution license (http://creativecommons.org/licenses/by/4.0/). 